\title{
Risking the Stability of EMU: the Asymmetric Application of the Stability and Growth Pact
}

\author{
Bartholomew Paudyn
}

\begin{abstract}
Fiscal profligacy poses a high risk to the credibility of Europe's common monetary policy and its ultimate objective of price stability. Unfortunately, the aim of preventing fiscally responsible states from being penalized by those with lax budgetary policies via inflationary pressures and interest rates is jeopardized as members breach the Stability and Growth Pact (SGP). Moreover, there are major institutional inconsistencies in how states are treated under the current framework as is exemplified by the November 2003 ECONFIN crisis. What is witnessed is an antagonistic relationship between the programmatic and operational dimensions of monetary governance. Does the fact that half the members who have adopted the euro have also breached its rules signal that surveillance as regulation is being displaced as a mode of governance? It calls for a reimaged spatial-temporal explanation of governance to adequately capture the political economy of EMU. At the core of EMU management are risk and uncertainty based modes of governing. Employing a governmentality approach, I argue that the audit is one prominent style of processing and institutionalizing risk as an aggregate future of monetary activity. By altering the administration and objects of risk governance the audit is perceived as reducing the susceptibility to failure. Hence, it has a performative function that extends beyond simply measuring deficit or debt to GDP performance and acts as a social and institutional process structuring a homogenous set of fiscal practices.
\end{abstract}




\section{Introduction}

Inexorably equated to the broader project of European integration, on January 1, 1999 Europe witnessed the irrevocable locking the conversion rates of eleven national currencies as they became denominations of the euro. This transition to Stage Three of the European Monetary Union (EMU) embodied the vision of Europe as an emerging, major player in international economic and monetary affairs (Dyson 2000; Verdun 2002). By January 2002, Greece had satisfied the convergence criteria and the last remnants of national legal tender disappeared. Having no equivalent in history, this is arguably the construction of a novel monetary space outside the parameters of the traditional nation-state with its own set of articulations and practices of governance and valuation (de Goede 2005). The euro involves a new "monetization of time-space, rendering the future calculable...and presupposes a particular rationalization of money and risk” (Pryke \& Allen 2000: 265). It is the management of the currency through the deployment of particular risk discourses and techniques, such as audits, which changes the perception of how money is governed in this evolving spatial-temporal order. What is witnessed is an antagonistic relationship between the programmatic and operational dimensions of monetary governance. On the one hand, risk management presupposes the "functional and political need to maintain myths of control...because it is what various constituencies and shareholders demand” (Power 2004: 10). Conversely, we are haunted by a consistent stream of failures that challenge our organizational capacity to control risk. This contradictory dynamic is one focus of this paper. It is reflected in the EMU as members transgress the very conditions established to prevent the destabilization of this monetary union, namely the Stability and Growth Pact (SGP). The SGP was devised as the anchor 
for the euro but it has come to symbolize its weakness (Gros et al. 2004). As a new style of governance, which shifts away from rule primarily based on the redistribution of resources or the mediation of social struggles, I posit that risk management reflects this tension between the programmatic and operational dimensions of governing EMU. Offering potential insights into the trajectory of EMU in its institutional capacity to manage and enforce this regulatory bloc by introducing new forms of governance and analytical instrumentality, the governmentality approach best captures this relationship.

Arguably, the underlying model for policy in EMU remains opaque as the different mandates assigned to the ECB (price stability) and member states (output stabilization) create a de facto policy conflict. What results is a high-risk strategy that is neither linear nor guaranteed in the successful development of a European monetary space. In effect, the SGP resembles a "contract” amongst countries that retain sovereignty over fiscal policies. Unlike a conventional contract, however, its politicized nature thwarts its enforcement by legal means. Thus, the "essence of the pact is not a mechanism of 'quasiautomatic sanctions' but the institutionalization of a political pledge to aim for low deficits” (Heipertz \& Verdun 2004: 770). Fiscal indiscipline is a political failure.

Thus, the primary research interest that I pursue in this paper considers how monetary governance is influenced by the politics of risk and uncertainty associated with fiscal profligacy. Does the fact that half the members who have adopted the euro have also breached its rules signal that surveillance as regulation is being displaced as a mode of governance? How does this differentiated assessment of SGP statutes problematize the changing governmental perceptions of the problem of European monetary management? More appropriately, how can the "audit", as a quantification of risk and institutionalization 
of value, be used to regulate this asymmetric application of the SGP? It calls for a reimaged spatial-temporal explanation of governance to adequately capture the political economy of EMU. Risk and uncertainty, as particular modes of governing, are instrumental in examining this problematic and helping understand (1) changing nature of the governance function, (2) the emergence of new authoritative institutions and mechanisms, (3) shifting power relations, wealth production and economic growth. Drawing attention to and historicizing the mechanisms of governance and the discourses embedded within these practices will reveal the audit to be a program for indirect control or "government at a distance”.

In deciphering the trajectory of the euro and analyzing how this space is governed, this argument is developed in five stages. The first section will detail the problematic. Next, I will introduce the reader to the conceptual territory of risk and uncertainty as modes of governance, which underpin the development of a European monetary space. The following section will demonstrate how mainstream integration theories are lackluster in explaining the SGP crisis. This literature privileges a mainly materialistic conception of power and neglects certain institutional mechanisms of monetary control, such as the audit, and associated relational forms of power. Having catalogued competing yet inadequate explanations of how the euro is governed and why clear regulations associated with its management are being so blatantly breached, I will proceed to introduce the governmentality approach as a better account of the phenomena in question. Here practices and technologies of risk management will be analyzed as these migrate into the EMU domain. From this discussion the various power systems at play in EMU will be revealed. 
Continuing, attention will be devoted to an investigation into how the audit acts as a force in the production of monetary objects of knowledge. I will operationalize how the audit functions as a technology of risk in the internalization of self-regulation, which may be deployed in promoting sustainable public finances and fiscal convergence.

\section{The Problematic}

Beset with problems right from its introduction in 1999, the euro quickly depreciated against the dollar and the entire regime looked vulnerable as Italy seemed unable to meet its budgetary obligations (Jones 2002). Fiscal profligacy continues to pose a high risk to the common monetary policy and its ultimate objective of price stability. Unsound budgetary policies threaten to increase inflationary pressures through fiscal expansion (Issing 2004: 9; Stiglitz and Greenwald 2003). As such, deficit financing undermines confidence in the price stability oriented monetary policy of the European Central Bank (ECB) as it is expected that government borrowing will be monetarily financed. Yet, little did the architects of EMU realize that this problem was only going to be exacerbated by the very champion of fiscal prudence, namely Germany, as well as a handful of other states. The Stability and Growth Pact (SGP), designed to ensure fiscal sustainability and prevent negative spill-over effects on interest rates across member states, has progressively come under attack as the rules prescribing government deficit (3\% of GDP) and debt (60\% of GDP) levels are breached. This asymmetric application of the SGP by governments undermines the stability of the euro and the common monetary policy, and exposes institutional inconsistencies apparent in governing the EMU. 
Built upon an asymmetric architecture with a common monetary policy but decentralized budgetary and wage setting arrangements, the EMU is hardly an Optimal Currency Area (OCA) (Mundell 1961). Underlying its fiscal framework is the mentality that privileges rules over discretion in the attempt to preserve the credibility of economic policy (Jespersen in Ljungberg 2004: 54). Although imposing a pro-cyclical policy acts as a constraint, states cannot be trusted from seeking the short-term political gains that result from a relaxed fiscal stance and free-ride as more responsible members adhere to the rules and shoulder a greater adjustment burden. Already the implication for potential abuse is apparent. The paradox, however, is that "the declared intention is to keep political discretion at a minimum in order to prevent opportunism by governments that are both subject to, and the executors of, the pact” (Schelkle 2005: 375). Here lies the dilemma in reconciling the programmatic aspect of EMU with its operational component.

Such a conflict of interest has stirred a contentious debate, which culminated in November 25, 2003 when the Council of Ministers in the Economic and Financial Affairs (ECOFIN) decided to suspend the Excessive Deficit Procedure (EDP) against the primary authors of the SGP, Germany and France. Acknowledging that they were in violation, ECOFIN rejected Commission recommendations to sanction the two members "sounding the death knell for the unloved Stability and Growth Pact (SGP) and also challenging recommendations to Member States under the Broad Economic Policy Guidelines (BEPGs)” (Begg \& Schelkle 2004: 86). In response, the Commission launched an action in the European Court of Justice (ECJ) questioning the legal basis for ECOFIN's decision. The ECJ sided with the Commission and annulled the November ruling. Nonetheless, the annulment did not indicate whether penalties should be imposed nor did 
it resolve the outstanding question of what to do next? On the one hand, what remains is a deficit bias of fiscal policies that is ultimately unsustainable and a behaviour that the SGP has apparently failed to eradicate. On the other hand, what is clear is:

that if the problem is primarily one of adherence to the rules, the priority should be to ensure rigorous implementation of the existing rules rather than to change them. At the same time, it is widely recognized that simply attempting to apply the existing rules after the watershed of November 2003 is not a viable option. Reestablishing a sense of ownership of the fiscal rules by all parties would be the precondition for their effective enforcement (Buti 2006: 9).

All this culminates in the need for a revamped approach to governing the fiscal operations of EMU.

\section{An Assemblage of Risk, Uncertainty and Calculations}

Problematizing and deconstructing the euro is instrumental in helping understand how governance is affected by the movement to a strong regulatory approach with an emphasis on quantitative targets, intervention and sanctions. This managerial approach posits that the future of the EMU should be governed through risk and uncertainty. As opposed to defining uncertainty as the incalculable risk, which is favoured by Ulrich Beck and most "risk society" theorists, I prefer to adopt the distinction that Pat O’Malley makes (Beck 1999; Ericson \& Doyle 2003). Whereas risk is a quantifiable frequency of an undesirable event, uncertainty may be understood as a subjective estimation, as the "fluid art of the possible” (O’Malley 2004: 5). However, this variation should not be interpreted as a rigid binary as they overlap in certain areas.

Understood nominalistically rather than as a totalizing theory, governance is always spatialized and temporal since it defines the area, both geographical and discursive, and 
time that authority may be exercised to achieve particular objectives. Accordingly, "power now has a new form: the knowledge and command of space” (Mitchell 2002: 90). It is this transmission and circulation of statistical information that emerges as a method of governing the euro (EU Presidency Conclusions - 22 and 23 March 2005). By scrutinizing vast amounts of economic code via the SGP, a reality is constituted embodying the values of organizational discipline and accountability. The "feedback loop is the locus of the critique of information” (Lash 2002: 112). One of the most visible feedback technologies in EMU regime of financial control is the audit. Even though it forms only a part of the broader regulatory framework, it works to institutionalize the EMU as a field of knowledge by framing problems in a largely quantitative manner while organizing relationships according to reference values. Audits grant power and authority to figures and abstract modeling (Strathern 2000). They "promise to compensate for the lack of government regulatory oversight and to provide accountability for organizational behaviour” (Courville et al 2003: 180). Moreover, audits increase transparency, which should be a key objective of any central bank.

The origins of this mode of governance are unique neither to EMU nor politics for that matter. They have migrated into the EMU domain from the private sector where risk analysis has been a powerful tool, dating from the beginning of the century to the current neoliberal push to minimize costs and maximize profits (Knight 1921). Michael Power has identified three primary elements that have been adopted by political authorities. All three are visible in EMU. The first concerns the emergence of risk-based "internal control” in redefining organizational governance. Early warning systems, such as those employed by ECOFIN, externalize institutional control arrangements. Next is "operational risk”, defined 
by the Basel Committee as "the risk of direct or indirect loss resulting from inadequate or failed internal processes, people and systems or from external events” (Basel 2001, http://www.bis.org/publ/bcbs_wp8.pdf ). Finally, the category of "reputational risk" connects the question of legitimacy and power with organizational identity (Power 2004).

The second understanding that we arrive at by problematizing the SGP is how new authoritative institutions and actors function within this monetary space. The ECB has replaced a plurality of decision-making centres. By moving to a monetary union, Europe has resolved the four elements of what Tommaso Padoa-Schioppa labels as the “inconsistent quartet” (Padoa-Schioppa 1998, http://www.ecb.int/press/key/date/ 1998/html/sp981203 1.en.html). The argument posits that fixed exchange rates, complete capital mobility, free trade, and autonomous national monetary policy cannot coexist simultaneously. With pegged rates and highly integrated financial markets "any attempt to pursue independent monetary objectives is almost certain...to result in a significant balance-of-payments disequilibrium, and hence provoke potentially destabilizing flows of speculative capital” (Cohen 1993: 147). Aside from the ECB, the European Court of Auditors (Court) reports on the accounts of the EU as a whole. The push to increase the surveillance authority and reach of the Court along with Eurostat, allowing for the direct assessment of the quality of financial operations of member states, only reinforces the notion that quantitative measures are necessary for the constitution of a healthy monetary space. Most revealing, however, is the recognition of subtle, institutional mechanisms of monetary control, such as the audit. Mainstream theories fail to analyze how these accounting systems constitute the real EMU space thereby rendering it governable in economic terms. 
Thirdly, not only is the territorial basis of power problematized but how power is exercised also changes with the construction of EMU. Transnational audits qualify and quantify economic activity according to new European benchmarks, thereby disrupting traditional forms of power rooted in the nation-state. Here power "works in part through its ability to name, to define and to describe certain people and places as being different from others” (Larner \& Le Heron 2004: 219). Being identified as a fiscally prudent state (e.g. Germany prior to 2002) is thought to translate into superior economic performance thereby bestowing a considerable amount of authority to shape the EMU agenda whereas fiscal profligacy does the opposite (e.g. Greece). Granted that money is the ultimate expression of political power relations, problematizing European monetary governance allows us to better understand how power functions. Determining where and how conduct is governed privileges particular regimes of power over others.

National ownership of the fiscal framework is essential to enhancing economic performance and preventing sovereign states from ceding too much power to unaccountable supranational bodies, such as the ECB or the Commission. Critics contend that the SGP is overtly rigid, "forcing countries to restrain fiscal policies in difficult times and exacerbate cyclical volatility" while "inhibiting growth by limiting useful public expenditures (e.g. on investment)" (Issing 2004: 9). However, the flouting of the SGP by member states and its asymmetric application by ECOFIN undermine the management of the common currency as serious harm that is inflicted on the credibility of a common monetary policy. A rules-based fiscal framework that fosters transparency, consistency and equal treatment is essential for establishing effective economic and monetary governance. Part of this involves establishing EU-wide standards for the compilation and 
reporting of fiscal statistics (COM (2004) 581). Next, strengthening EU governance of fiscal statistics necessitates enhancing Eurostat's operational capacity by granting it right to check government accounts directly. To achieve sound budgetary policies across diverse states requires a regulatory approach that adequately quantifies levels of assurance and institutionalizes the value of fiscal conduct. Direct audits executed by Eurostat may be capable of just that and may increasingly serve to discipline national authorities to adhere to the fiscal statutes. Here discipline is a positive force as it fosters the internalization of self-regulation. Embedded within regulatory practices are discourses of risk and uncertainty, which are institutionalized through the deployment of the audit as a calculative form of control. Minimizing exposure to risk and uncertainty, EMU "governance is not about policing or surveillance in the normal sense of external observation" but "has more to do with attempts to re-order the collective and individual selves that make up organizational life” (Power 1997: 123). This entails accepting the superiority of knowledge derived from mathematical methods and technical expertise as a mode of governance.

\section{European Integration Theories}

Transposed on a larger scale, fiscal control does not reside in a central European authority but is premised on the notion of self-regulation by member states. Undoubtedly, this is one of the reasons why the SGP is so blatantly flouted. With the absence of any credible, overarching supervision or enforcement, members are more prone to violating its conditions if it suits their interests. Nevertheless, the idea of transferring economic command to the supranational level is not being seriously entertained as fiscal 
sovereignty is a sacred cow of the state (Puetter 2004). The governmentality literature adequately accounts for this phenomenon as it captures the various layers of economic and monetary regulation and the risk management practices and discourses inherent in them. Such an understanding of EMU lends itself well to the network metaphor of connecting different spaces at the cores and peripheries. Political power is defined by the proximity to European monetary centres (i.e. Frankfurt) in a hierarchy of nodes and areas that are connected by flows of individuals, capital and information. However, given its nonlinear and discontinuous character, this network is prone to multiple failures. Making these risks and uncertainties auditable and governable is how the EMU operates. Yet, before forging ahead with the merits of this approach in relation to the problem of monitoring and auditing failure, namely risk regulation, it is wise to develop a better understanding of one of the more compelling theoretical explanations.

At a time when the nation-state is reasserting itself in the process of European integration, intergovernmentalists emphasize the national interests of Germany, France and Portugal, to name but a few, as the key factors behind the turmoil (Hodson 2004: 231). Building on earlier analyses of thinkers such as Andrew Moravcsik (1998) and Geoffrey Garrett (1995), the relevant decision-making mechanism is an institutionalized form of inter-state bargaining. Within the European Council but particularly within ECOFIN, member governments are dominant in determining the course of EMU (Scharpf 1999; Zangl \& Rittberger 2006). Here the influence of supranational actors is considered as limited. They are important insofar as they inform the preferences of national governments. Intergovernmentalism serves to clarify this interaction and predicts outcomes based on the relative power of member states. 
It is intergovernmentalist preoccupations with materialism and individualistic explanations of behaviour that allows them to draw a causal conclusion between the relative power of France and Germany and their escape from sanctions in 2003 (Chang 2006). During the first years of Stage Three, larger countries failed to consolidate their public finances sufficiently to attain the position of "close to balance or in surplus" that constitutes the medium-term rule at the heart of the SGP (Council Resolution No 1466/97). Given the prolonged economic slowdown, the French and German deficits breached the 3 percent limit in 2003 (4.1\% and 3.9\% respectively) and subsequent years. Together they dominated ECOFIN and therefore managed to orchestrate a blocking coalition against the Commission’s proposal to begin the EDP (de Haan et al 2004: 236). Again, national interests superseded those of the broader community and supranational institutions, such as the ECB. In the end, SGP dictates are enforced by ECOFIN, which "manifestly does not have the collective capacity to commit itself to an impartial, consistent enforcement of the rules” (Buiter 2003: 15).

Arguably, most versions of intergovernmentalism are prone to the charge of reductionism with their preoccupation with a unitary state. They "offer refined decisionmaking and interest aggregation theories against the background of game theoretic concepts, while still lacking a genuine interest theory” as "interests and preferences as exogenous to the model” (Wolf in Verdun 2002: 30). Moreover, these accounts fail to capture how monetary integration is shaped by societal actors. 


\section{Analytics of Government}

As mentioned above, an analytics of government is more conducive to conceptualizing EMU as a network/assemblage of a diverse set of practices in which discourses of risk and uncertainty are embedded. According to Mitchell Dean, an assemblage "is a way of thinking about entities as multiplicities rather than unities, as complex ensembles of discontinuous elements and forces bound by heteromorphic relations” (Dean 1996: 55). Irreducible to a basic essence, the assemblage does not privilege some fixed state of affairs but is malleable, reflecting the changing problem of government with the asymmetric application of the SGP. No longer is the primary focus of EMU defined as the direct "control over specifically capitalist processes, the redistribution of resources, or the mediation of social struggles, but in terms of meta-processes of knowledge production and problem solving” (Barry \& Walters 2003: 319). Increasingly, it relies on performative technologies to project a particular vision of what is considered appropriate behaviour in order to enforce a homogenous set of fiscal practices across different contexts. Government seeks to address the problem of controlling the economy, which has itself become an object of rule. Making sense of how a space labeled "EMU” is organized and rendered thinkable for the purposes of government will allow for an assessment of its relative merits as a field of intervention. Furthermore, this shift privileges membership constituted in economic terms making the evaluation of "good standing" all the more dependent on expertise and technologies of risk management. Governmentality studies concentrate on how the EMU is constructed as an object of knowledge and how its "space, movement, sequence and position" are manipulated by technologies such as the audit (Mitchell in Steinmetz 1999: 86). 
Monetary relations are exemplary of "socio-technical” links where actuarial/ expertise knowledge shapes the cultural and intersubjective aspects of life (Mauer 2002: 16). It is a blend of statistical information and societal expectations, which produces a notion of how we should organize and interact within the economy. Not only is currency a material medium of exchange but it is a discursively constituted practice of representation (de Goede 2005). Intergovernmentalist explanations fail to recognize this social construction of the euro. Instead we are presented with either ex ante bargaining scenarios. Being contestable and historically contingent a governmentality approach is instructive to deciphering how the euro emerges as a problem of government. With the shift to EMU, no longer are currency challenges restricted to the exclusive authoritative domain of state sovereignty, even though the ECOFIN crisis demonstrates that this cannot be readily discounted. Monetary authority is increasingly dislodged from this traditional locus and centred in the ECB, necessitating a revamped approach to governing monetary relations in the emerging spatial order. Problematizing the asymmetric application of the SGP reveals how power is exercised in the construction of EMU conceived of as a struggle between national and European versions of risk-centred governance.

Given the substantive ambiguity associated with the practice of auditing, an array of power systems is identifiable that is relevant for conceptualizing the audit as a territory of government. By remanagerializing risk audits help uphold the myths of control as calculations encourage conformity to a set standard. With the emergence of risk and uncertainty as dominant modes of rule, "sovereignty" and "discipline" have not been completely displaced by the art of "government" (Foucault in Burchell et al. 1991: 101). Rather the idea of a government of economy introduces a self-regulating element to the 
organization of EMU. The SGP envisioned members as enterprising subjects entrusted with the responsibility of prudently managing their fiscal books. Audits function as a subtle mechanism reinforcing this sovereignty. The chance that members will deviate from their expected roles ushers in a politics of uncertainty and the need for self-regulation. Accordingly, the audit is valuable in addressing not only questions of discipline but government as well. Recognized as the continuous exercise of power through surveillance, individualization and normalization it works by constituting the subject as an object of knowledge (Barry et al 1996: 8). In accordance, Michael Power notes that "governance is not to do with policing or surveillance in the normal sense of external observations” but "has more to do with attempts to re-order the collective and individual selves that make up organizational life” (Power 1997: 146). The governmentality literature concentrates on discipline, sovereignty and government in the contested production of modern subjects and rationalities underlying the spatial-temporal organization of EMU.

Aside from discipline and government, "control” is another power system that is relevant when discussing the SGP. Acknowledging that failure is possible across multiple sites of this assemblage labeled EMU, the “modulation” of conduct programmed into daily practice may reveal how governance is transforming with the shift to modes of risk and uncertainty (Deleuze 1995). Whereas discipline entailed both individualization and normalization, regimes of control are concerned with the "administrative management of populations at risk, anticipating 'possible loci of dangerous irruptions through the identification of sites statistically locatable in relation to norms and means"” (Castel in Rose 1999: 235). Therefore, the objective is to regulate deviance rather than to reform the 
actor. This capacity and propensity of member states to violate the rules and norms of monetary union is established through codes, accounts and feedback loops.

A caveat is in order when discussing the variety of power systems at play in the EMU. In the first instance, November 2003 called attention to the potential deterioration of the normalizing force implicit in the SGP and its related arsenal of technologies. Member states readily breached the deficit and debt ceilings, questioning the disciplinary power of accounting measures. Portugal joined the ranks of Germany and France in 2003 as being subject to the EDP. Shortly after, in June 2004, the Netherlands was added to the list of delinquents and advised in a formal 'early warning' from ECOFIN. Since then Greece and Italy have come under scrutiny for lax fiscal positions leading to violations of the SGP (http://europa.eu.int/scadplus/leg/en/lvb/l25019.htm). Therefore, half the members who have adopted the euro have breached its rules. Is surveillance as regulation being displaced as a mode of governance? Could "actuarial” power prove to be more dominant in risk-centred governance? Assigning actors to risk pools recasts them as calculative and prudent liberal subjects capable of controlling their susceptibility to fiscal profligacy (Simon 1988; Ewald in Burchell et al 1991). If so, would an alternative form of fiscal coordination as a form of collective insurance be more effective in achieving stabilization with “actuarial” power as its most prominent articulation? Rather than continuing with the "disciplinarian device" rationality of the present SGP, a "stabilization as insurance" approach to fiscal policy coordination pools the uncertainty of national economies experiencing asynchronous business cycles at a higher level of aggregation (Schelkle 2005: 378). Compensation as opposed to punishment would be favoured in the event of a 
negative shock. However, this should not be construed as a perfect solution as certain inconsistencies surface that detract from its value; its tolerance for variation being one.

Marieke de Goede notes that "governing through statistics is both an individualizing and a totalizing power" (de Goede 2005: 92). Managing risk and uncertainty through the audit also involves identifying and classifying the potential deviance of a collective without necessarily reforming the individual subject. This regulatory approach is associated with an "actuarial” form of power in that it seeks to "alter the physical and social structures within which individuals behave” without directly changing the actor (Simon 1988: 773). Incapacitation of the aggregate group at risk is the objective. Aside from this feature, actuarial techniques possess two further characteristics. Risk classification often produces unique categories that are removed from daily experience. Similar to the practice of designating an object as "auditable", resistance is more difficult given it is not readily recognizable. Finally, actuarial technologies "act in situ rather than by separation or exclusion of deviant cases, and as a by-product have less need to be coercive” (O’Malley in Barry et al 1996: 191). By signaling who is more prone to fiscal profligacy the audit constrains some degree of autonomy as all member states are part of a common monetary pool. This distributive characteristic is visible when EMU risk management practices differentiate between the prudent "Scandinavian" states and the more fiscally lax “Mediterranean” economies (Jones 2002). Acknowledging that:

uncertainty is a characteristic modality of liberal governance that relies both on a creative constitution of the future with respect to positive and enterprising dispositions of risk taking and on a corresponding stance of reasonable foresight or everyday prudence (distinct from both statistical and expert-based calculation) with respect to potential harms, 
actuarial techniques may provide an alternate method for dealing with the asymmetric application of the SGP (O’Malley 2000: 461). Spreading and minimizing the dangers of fiscal uncertainty through an insurance-like scheme may help reinforce stability in EMU.

\section{Auditable Objects of Governance}

Having established the EMU as a space of monetary activity with identifiable parameters, power systems and mentalities of rule predicated on risk and uncertainty, I now proceed to investigate how the audit acts as a force in the production of monetary objects of knowledge. Understood as mechanisms through which risk is portrayed for managerial purposes, audits:

can be described in as an instrument of definitional risk management, effectively subsuming those risks which are open to social definition and construction within a new managerialism with its own esoteric risk knowledges (Power in Hopwood \& Miller 1994: 312).

By transforming the administration and objects of risk governance, the audit is perceived as reducing the susceptibility of the SGP to failure. Hence, it has a performative function that extends beyond simply measuring performance, according to benchmarks, to being a social and institutional practice. Embodying the principles of accountability, organizational discipline and transparency the audit attempts to classify an unknown future. "Auditability" renders subjects and risks manageable as it "travels well across space and time, is capable of being propagated in a multitude of locales, channeling and organizing activities and linking centres of calculation to sites of implementation according to new vectors” (Rose in Barry et al 1996: 55). Being both temporal and spatial, governing through statistics reveals certain regularities about the political economy of EMU. Risk sharing in the SGP is renegotiated by making the time frame for correcting excessive deficits more conditional on economic growth. Although "accepted for the close to balance provision as it supports 
stabilization", it is inappropriate for the "EDP where the risks to macroeconomic stability were considered more important than the desire for risk sharing” (Schuknecht 1994: 23). Recognizing the differences in degree in which these behaviours and events are susceptible to failure offers the opportunity of stability through regulation. In this manner, the audit “creates specific patterns of visibility and performativity” as it institutionalizes a risk management system geared to securing a homogenous set of fiscal practices across different European contexts (Power in Hopwood \& Miller 1994: 308).

Communicating economic irregularities is essential for the successful functioning of a reformed SGP, especially in a system of national accounts that is hampered by delays and the manipulation of data. One only has to look to Portugal in 2001 or the more dire case of Greece, which as it turns out had swollen deficits in excess of 3\% of GDP since 1997 (http://europa.eu.int/scadplus/leg/en/lvb/l25071.htm). Hence, the availability of accurate information is vital and:

the new Pact acknowledges the importance of high-quality, timely and reliable fiscal statistics and pledges to ensure the independence, integrity and accountability of both national statistical offices and Eurostat. The availability of better statistics should be complemented by a more comprehensive surveillance of fiscal variables (Buti 2006: 15).

Problematizing European monetary affairs in terms of deficit and debt to GDP ratios, among a variety of statistical variables, privileges the audit as one particular style of processing risk as this space called EMU is understood as a series of numerical propensities, which may be verified against a standard. As such, solutions to guarding against adverse outcomes are conceptualized in terms of expertise and technologies of risk. Good governance, however, relies on multiple principles of accounting ranging from surveillance to verification to supervision (Deuchars 2004: 164). The audit is one part of 
this configuration but it is also arguably one of the most visible and powerful institutions of risk processing (Power 2004). Given the vast spatial and informational geography of EMU it is inefficient and extremely costly to directly monitor the monetary practices of each member state in an overarching fashion. The audit performs such a "governance-at-adistance” function as a "responsibilizing technology" (Miller 1992). It categorizes objects of EMU and makes them intelligible according to a rationality that emphasizes discipline and accountability with respect to economic conduct. Modes of financial calculation become the dominant form of rule, transforming how objects of knowledge are conceived as a problem of monetary governance. Timetables, balance sheets and other disciplinary institutions regulate EMU conduct. Audits exemplify one such technology as they assign a risk value to the fiscal conduct of member states, indicating how far from the prescribed SGP policy objectives they are operating, thereby rendering them auditable.

Since the suggestion to establish independent monitoring bodies at the national level was rejected, enforcement must take on a more discrete form in addition to the direct monitoring by Eurostat. Member states are accorded freedom in the management of their economic affairs while simultaneously being transformed into visible, calculable objects of government. Such a spatial configuration allows EMU “to be represented as a series of financial flows, enables the evaluation of these spaces according to a financial rationale and allows particular forms of action upon component parts of the organization” (Miller 1992: 76). We come to recognize and understand Euro-zone by the monthly or quarterly balance of payments statistics disseminated by the ECB or that indicator-based forecasts for Eurozone GDP growth show a range of $0.4 \%$ to $0.8 \%$ for the first quarter of 2006 (http://epp. eurostat.cec.eu.int/cache/ITY_OFFPUB/KS-BJ-06-002/EN/KS-BJ-06-002-EN.PDF.) 
Liberty also reveals the "uncertainty" inherent in governing the EMU as estimating if and when a member will breach the SGP remains subjective guesswork. Uncertainty challenges a fundamental assumption underpinning risk; that the future reproduces the past. Unfortunately, it is seldom analyzed as a distinctive modality of governance.

Harmonization is central to this programmatic and stipulates that all member states implement the Accounting Directives (Fourth European Company Law Directive \& Seventh Consolidated Accounts Directive). Instead of devising its own set of rules, the EU decided to import International Accounting Standards (IAS) (van Hulle in Leuz et al 2004: 349). The intent was to subject national regulatory schemes to international pressures for harmonization. Yet, harmonization is not equivalent to uniformity. The differences between the financial statements of enterprises need only to be reduced so that they do not impede the efficiency of the European capital market. In practice, however, the push towards harmonization through the directives has seen limited success. National accounting systems still exist and globalization has curtailed the competitiveness of EU firms (Flower 2002: 211). Nevertheless, accounting measures designed to regulate the neoliberal private sector are increasingly being transposed onto the supranational level in order to govern the accounts of states themselves. With the "admixture of administrative and political themes...public sector auditing implicates questions about the distribution of authority and control in a way that financial auditing does not” (Power 1997: 45).

Recently, imperfect links with national accounting agencies coupled with what Harden identifies as “a spending culture in conflict with constraint values”, have impeded the precise and efficient monitoring of EU accounts (Harden in Power 1997: 48). Acknowledging the deficiencies in the compilation and reporting of fiscal data (i.e. 
Greece 2004), the Commission has issued a "European Governance Strategy for Fiscal Statistics" with the aim of enhancing the integrity and accountability of budgetary management and by extension the SGP (COM (2004) 832). To strengthen the governance of fiscal statistics the Commission proposed the following three measures:

- first, the relevant provisions on the quality of statistical data used in the context of the Excessive Deficit Procedure should be clarified. A proposal will be presented, aiming at supplementing the existing rules by strengthening data monitoring mechanisms. Under existing law, the Commission (Eurostat) lacks the power to monitor government accounts directly. The existing set of rules needs to be extended to ensure that Eurostat, as the statistical authority, can carry out effective checks on the data notified by Member States

- second, the operational capacities of the Commission, most notably Eurostat and of the Directorate-General for Economic and Financial Affairs need to be improved. Systematic planning of existing missions, plus longer and more in-depth verification missions, are required.

- third, there is a need to establish Europe-wide standards as regards the independence, integrity and accountability of the national statistical institutes. (http://epp.eurostat.cec.eu.int/cache/ITY_PUBLIC/FISCAL_STATISTICS/EN/ FISCAL_STATISTICS-EN.PDF).

These proposed reforms that would allow Eurostat to directly audit the books of member states enhance surveillance thereby heightening the potential disciplining force exerted on national governments to respect fiscal regulations. Few would dispute the claim that the current enforcement structure is weak. For real reform to occur, however, some degree of national fiscal sovereignty must be relinquished. Audits strike a necessary balance between maintaining fiscal sovereignty and accountability. However, rather than governing through risk, as is evident with regards to the ECB, within regulatory policy audits it is discourses of "uncertainty" which are embedded. Given this lack of knowledge about an unwanted outcome, generating quantitative guidelines for monitoring contingency is difficult. As is currently the case with the SGP, states may violate whatever regulations 
are tabled and in the process jeopardize the monetary union. No statistical method exists for predicting which state will breach the pact, when and how it will happen. Hence, these subjective probabilities must be governed through uncertainty as the unanticipated contingency is ever present making discipline all the more significant.

\section{Conclusion}

The focus of this paper is to analyze how monetary management is affected by the divergent application of SGP statutes. There is a visible tension between the Commission and ECOFIN, which the ECJ ruling did not reconcile. Essentially, the court annulled the November decision clarifying the procedural dimension but it did not direct ECOFIN to impose any sanctions. Now the Commission must prepare a fresh recommendation, which ECOFIN may reject (de Haan et al 2004). Arguably, this renders the SGP virtually impotent as national governments will avoid imposing penalties onto themselves. Both scenarios pose a high risk to the existence of the fiscal framework even in its revamped configuration, effectively jeopardizing the credibility and stability of the common monetary policy. Therefore, new forms of governance are necessary in order to prevent another potentially more damaging crisis. What the governmentality approach offers is a new analytical instrumentality with which to understood and even manage the political economy of EMU. In the process, we come to terms with how the audit achieves its authority and how it is being redefined within the broader EMU regulatory context. Mainstream theories fail to recognize how the audit functions as a normalizing mechanism for monetary control. What this omits is an understanding of EMU as a unique space, imbued with its own set of discourses and their practices of governance. Two of the most dominant are those of risk and uncertainty. 


\section{Bibliography}

Barry, Andrew, Thomas Osborne and Nikolas Rose, eds. 1996. Foucault and Political Reason. Chicago: University of Chicago Press.

Barry, Andrew and William Walters. 2003. "From EURATOM to 'Complex Systems': Technology and European Government”. Alternatives. 28: 305-329.

Basel Committee on Banking Supervision. 2001. Sound Practices for the Management and Supervision of Operational Risk (Basel: Bank for International Settlements, December).

Beck, Ulrich. 1999. The World Risk Society. Malden: Blackwell Publishers.

Begg, Iain and Waltraud Schelkle. 2004. "The Pact is Dead: Long Live the Pact”. National Institute Economic Review. 189: 86-98.

Buiter, W. H.. 2003. "How to Reform the Stability and Growth Pact?”, EBRD Mimeo.

Burchell, Graham, Colin Gordon and Peter Miller. 1991. The Foucault Effect. Chicago: Chicago University Press.

Buti, Macro. 2006. "Will the New Stability and Growth Pact Succeed? An Economic and Political Perspective”. http://europa.eu.int/comm/economy_finance/publications leconomic_papers/2006/ecp241en.pdf).

Chang, Michelle. 2006. "Reforming the Stability and Growth Pact: Size and Influence in EMU Policymaking”, Journal of European Integration, 28 (1): 107-120.

Cohen, Benjamin. ed. 1993. The International Political Economy of Monetary Relations. London: Edward Elgar Publishing.

Dean, Mitchell. 1996. "Putting the Technological into government”. History of the Human Science. 9(3): 47-68.

De Goede, Marieke. 2005. Virtue, Fortune, and Faith. Minneapolis: University of Minnesota Press.

De Hann, J, H. Berger and D.-J. Hansen. "Why the Stability and Growth Pact Failed?” International Finance. 7.2 (2004): 235-260.

Deleuze, Gilles. 1995. Negotiations. Translated by M. Joughin, New York: Columbia University Press.

Deuchars, Robert. 2004. The International Political Economy of Risk. Burlington: Ashgate 


\section{Publishing Company.}

Dyson, Kenneth. 2000. The Politics of the Euro-Zone. New York, Oxford University Press.

Ericson, Richard V., Aaron. Doyle and Dean. Barry. 2003. Insurance as Governance. Toronto: U of T Press.

European Central Bank: http://www.ecb.int/home/html/index.en.html.

European Parliament: http://www.europarl.eu.int

European Union: http://europa.eu.int

Flower, J. 1994. The Regulation of Financial Reporting in the Nordic Countries. Stockholm: Fritzes.

Garrett, Geoffrey. 1995. “The Politics of Legal Integration in the European Union”. International Organization. 49 (1): 171-181.

Gros, Daniel, Thomas Mayer and Angel Ubide. 2004. "The dog that lost its bark: The Commission and the Stability Pact”, CEPS Policy Brief, 18.

Heipertz, Martin and Amy Verdun. 2004. "The dog that would never bite? What we can learn from the origins of the Stability and Growth Pact”. Journal of European Public Policy. 11(5): 765-80.

Hodson, Dermont. 2004. "Macroeconomic co-ordination in the euro area: the scope and limits of the open method", Journal of European Public Policy, 11(4): 231-248.

Hopwood, Anthony and Peter Miller, eds. 1994. Accounting as Social and Institutional Practice. Cambridge: Cambridge UP.

Issing, Otmar. 2004. "The Stability and Growth Pact: The appropriate fiscal framework for EMU”, International Economics and Economic Policy. 1: 9-13.

Jones, Erik. 2002. The Politics of Economic and Monetary Union. New York: Rowman \& Littlefield Publishers.

Knight, Frank. 1921 (1964). Risk, Uncertainty and Profit. New York: A.M. Kelley.

Larner, Wendy and R. Le Heron. 2004. “Global Benchmarking.” In Global Governmentality: Governing International Spaces, edited by Wendy Larner and William Walters. London: Routledge.

Lash, Scott. 2002. Critique of Information. London: Sage Publications. 
Leuz, Christian, Dieter Pfaff and Anthony Hopwood. 2004. The Economics and Politics of Accounting. New York: Oxford University Press.

Ljungberg, Jonas, ed. 2004. The Price of the Euro. New York: Palgrave Macmillan.

Mauer, Bill. 2002. "Repressed futures: financial derivatives’ theological unconscious”. Economy and Society. 31(1): 13-36.

Miller, Peter. 1992. "Accounting and Objectivity: the invention of calculating selves and calculable spaces”. Annals of Scholarship. 9: 61-86.

Mitchell, Tim. 2002. Rule of Experts. Berkeley: University of California Press.

Moravcsik, Andrew. 1998. The Choice for Europe. New York: Cornell University Press.

Mundell, Robert. 1961. “A Theory of Optimum Currency Areas”, American Economic Review. 51 (4).

O’Malley, Pat. 2000. “Introduction: configurations of risk”. Economy and Society. 29 (4): 460-84.

O’Malley, Pat. 2004. Risk, Uncertainty and Government. London: Glasshouse Press.

Power, Michael. 1997. The Audit Society : rituals of verification. New York: Oxford University Press.

Power, Michael. 2003. “Evaluating the audit explosion”, Law \& Policy. 25 (3): 115-202.

Power, Michael. 2004. The Risk Management of Everything: rethinking the politics of uncertainty. London: Demos.

Pryke, Michael and John Allen. 2000. "Monetized time-space: derivative-money’s 'new imaginary’”, Economy and Society. 29 (2): 264-284.

Puetter, Uwe. 2004. "Governing informally: the role of the Eurogroup in EMU and the Stability and Growth Pact”, Journal of European Public Policy. 11 (5): 854-870.

Rose, Nikolas. 1999. Powers of Freedom. Cambridge: Cambridge University Press.

Scharpf, Fritz. 1999. Governing in Europe: Effective and Democratic? Oxford: OUP, 1999.

Schelkle, Waltraud. 2005. "The Political Economy of Fiscal Policy Co-ordination in EMU: From Disciplinarian Device to Insurance Arrangement”, Journal of Common Market Studies. 43 (2): 371-91.

Simon, Jonathan. 1998. "The ideological effects of actuarial practices”. Law and Society 
Review.22.

Steinmetz, G, ed. 1999. State/Culture: State Formation after the Cultural Turn. Ithaca: Cornell UP.

Stiglitz, Joseph and Bruce Greenwald. 2003. Towards a New Paradigm in Monetary Economics. Cambridge: Cambridge University Press.

Strathern, Marilyn, ed. 2000. Audit Cultures. Anthropological studies in accountability, ethics and the academy, (EASA Series) London: Routledge.

Verdun, Amy, ed. 2002 The euro: European Integration Theory and Economic and Monetary Union. Lanham, Md.: Rowman \& Littlefield Publishers.

Zangl, Bernhard and Volker Rittberger. 2006. International Organisations. Polity, Policy, and Politics Houndsmills: Palgrave. 